\title{
PENGARUH MODEL PEMBELAJARAN KOOPERATIF TIPE NUMBER HEADS TOGETHER TERHADAP HASIL BELAJAR MATEMATIKA SISWA KELAS VIII SMP NEGERI 2 TONGKUNO
}

\author{
Mustika ${ }^{\text {I) }}$,Suhar ${ }^{2)}$, La Ndia ${ }^{3)}$ \\ ${ }^{1)}$ Mahasiswa Jurusan Pendidikan Matematika, ${ }^{2,3)}$ Dosen Jurusan Pendidikan Matematika \\ FKIP Universitas Halu Oleo Kendari oleh email: ${ }^{1)}$ mustikafkip95@yahoo.com; \\ ${ }^{2)}$ suhar_fkipmat@yahoo.com; 3) alndifiat@gmail.com
}

\begin{abstract}
Abstrak
Penelitian ini bertujuan untuk mengetahui: (1) gambaran hasil belajar matematika siswa kelas VIII SMP Negeri 2 Tongkuno yang diajar dengan model pembelajaran kooperatif tipe NHT (2) gambaran hasil belajar matematika siswa kelas VIII SMP Negeri 2 Tongkuno yang diajar dengan model pembelajaran Konvensional (3) apakah model pembelajaran tipe NHT berpengaruh terhadap hasil belajar matematika siswa kelas VIII SMP Negeri 2 Tongkuno. Populasi dalam penelitian ini adalah seluruh siswa kelas VIII SMP Negeri 2 Tongkuno yang terdiri dari 2 kelas VIII $_{1}, \mathrm{VIII}_{2}$. Desain penelitian ini adalah the posttest only control group design. Hasil yang diperoleh dalam penelitian ini : (1) Hasil belajar matematika siswa yang diajar dengan model pembelajaran kooperatif tipe NHT pada materi pola bilangan dengan nilai rata-rata 75,41 (2) Hasil belajar matematika siswa yang diajar dengan model pembelajaran konvensional pada materi pola bilangan dengan nilai rata-rata 65,56 (3) model pembelajaran kooperatif tipe NHT berpengaruh terhadap hasil belajar matematika.
\end{abstract}

Kata Kunci : model pembelajaran kooperatif, model pembelajaran tipe NHT, h asil belajar siswa

\section{THE EFFECT OF NHT COOPERATIVE LEARNING MODEL (NUMBER HEADS TOGETHER) ON MATHEMATICAL LEARNING OUTCOMES OF CLASS VIII TONGKUNO 2 STATE SMP}

\begin{abstract}
This study aims to find out: (1) an overview of mathematics learning outcomes of class VIII students of SMP Negeri 2 Tongkuno taught by cooperative learning model NHT type (2) description of mathematics learning outcomes of eighth grade students of SMP Negeri 2 Tongkuno taught by conventional learning models (3) Does the NHT type learning model affect the mathematics learning outcomes of Grade VIII students of SMP Negeri 2 Tongkuno. The population in this study were all eighth grade students of SMP Negeri 2 Tongkuno consisting of 2 classes. The design of this study is the posttest only control group design. The results obtained in this study: (1) Mathematics learning outcomes of students who were taught by cooperative learning model NHT type on material pattern numbers with an average value of 75.41 (2) Mathematical learning outcomes of students taught with conventional learning models on pattern material numbers with an average value of 65.56 (3) cooperative learning type NHT model affect the learning outcomes of mathematics.
\end{abstract}

Keywords: cooperatif learning model, NHT type learning model, student learning outcomes 


\section{Pendahuluan}

Pendidikan sekolah merupakan amanah untuk mengembangkan sumber daya manusia yang dilakukan secara sistematis, praktis, dan berjenjang. Dalam pelaksanaan mengajar di sekolah, guru mempunyai peranan yang sangat besar demi tercapainya proses belajar yang baik. Sehubungan dengan peranan ini, seorang guru dituntut untuk mempunyai kompetensi yang memadai dalam hal pengajaran di sekolah. Rendahnya kompetensi guru menyebabkan pelaksanaan pembelajaran menjadi kurang efektif yang mengakibatkan siswa tidak senang pelajaran sehingga mereka dapat mengalami berbagai kesulitan belajar dan prestasi belajarnya pun menurun.

Aktifitas kehidupan manusia sehari-hari hampir tidak pernah terlepas dari kegiatan belajar, baik ketika seseorang melaksanakan aktifitas sendiri, maupun di dalam suatu kelompok tertentu. Dipahami ataupun tidak dipahami, sesungguhnya sebagian besar aktifitas didalam kehidupan sehari-hari kita merupakan kegiatan belajar. Tidak ada ruang dan waktu dimana manusia dapat melepaskan dirinya dari kegiatan belajar, dan itu berarti pula bahwa belajar tidak pernah dibatasi usia, tempat maupun waktu, karena perubahan yang menuntut terjadinya aktifitas belajar.

Belajar adalah upaya sadar yang dilakukan oleh individu terhadap orang lain untuk memperoleh berbagai macam kemampuan, keterampilan, dan sikap melalui serangkaian proses belajar yang pada akhirnya akan menghasilkan perubahan tingkah laku pada individu yang belajar. Salah satu bidang ilmu pengetahuan adalah matematika.

Matematika sebagai salah satu bidang studi yang sangat mendukung perkembangan ilmu pengetahuan dan teknologi memiliki peran yang sangat penting dalam bidang pendidikan. Hal ini disebabkan karena matematika sangat berkaitan dengan bidang studi lain serta kehidupan sehari-sehari, sehingga pelajaran matematika diberikan disemua jenjang pendidikan mulai dari pendidikan dasar, pendidikan menengah, dan sebagian perguruaan tinggi.

Keberhasilan dalam proses belajar mengajar biasanya diukur dengan keberhasilan siswa dalam memahami dan menguasai materi yang diberikan. Semakin banyak siswa yang dapat mencapai tingkat pemahaman dan penguasaan materi maka semakin tinggi keberhasilan dari pengajaran tersebut.

Salah satu mata pelajaran yang mempunyai prestasi belajar rendah di sekolah adalah matematika. Mata pelajaran ini termasuk mata pelajaran yang disegani oleh siswa, karena untuk dapat memahami materi yang terkadang didalamnya perlu adanya kejelian dalam berfikir, ketelitian dalam pengajaran, dan waktu yang cukup untuk mengadakan latihan-latihan, baik pada jam pelajaran maupun di luar jam pelajaran. Matematika termasuk salah satu kemampuan dasar yang harus dikuasai siswa disamping membaca dan menulis. Hal ini dikarenakan siswa sering takut terhadap matematika, mereka menganggap matematika sebagai pelajaran yang sulit dan rumit.

Banyak faktor yang mempengaruhi tinggi rendahnya hasil belajar siswa di kelas, salah satunya adalah model pembelajaran yang digunakan oleh guru. Berdasarkan observasi awal pada tanggal 19 Desember 2017, nilai ratarata pada masing-masing kelas yaitu kelas VIII $_{1}$ yaitu 58,35 dan pada kelas $\mathrm{VIII}_{2} 58,21$, dan ditemukan bahwa pembelajaran matematika di SMP Negeri 2 Tongkuno menggunakan model pembelajaran yang bervariasi yaitu ceramah, dan tanya jawab. Namun dalam proses pembelajaran, masih banyak ditemukan siswa yang pasif, bahkan ada beberapa siswa yang bermain.

Proses pembelajaran di sekolah atau di kelas hendaknya guru memperhatikan kondisi individu dan siswa karena merekalah yang akan belajar. Selama ini guru hanya memperhatikan kondisi anak didik secara keseluruhan, tidak perorangan maupun kelompok. Sehingga perbedaan individual dan anak didik kurang mendapat perhatian. Selain itu, gejala yang lain dapat dilihat dalam proses pembelajaran selama ini yaitu sebagian besar guru menggunakan metode pengajaran yang cenderung sama setiap kali proses pembelajaran berlangsung. Metode yang sering digunakan adalah metode ceramah yaitu pengajaran yang berpusat pada guru.

Kriteria tenaga kerja yang dibutuhkan selain kemampuan akademik adalah terampil berkomunikasi secara tertulis maupun lisan, berintegritas, bisa bekerja sama, beretika kerja, terampil menganalisa, fleksibel atau mudah beradaptasi, memiliki keterampilan interpersonal (bisa membangun hubungan baik dengan orang lain), memiliki motivasi,inisiatif, kreativitas, terampil mengoperasikan komputer, dan 
mendetail. Melihat hal tersebut, dunia pendidikan memegang peranan penting dalam menyiapkan sumber daya manusia yang mempunyai multi keterampilan yang dibutuhkan dalam dunia kerja. Pendidikan diharapkan mampu membekali lulusan yang mempunyai keterampilan kecakapan hidup.

Melihat permasalahan yang telah dipaparkan tersebut, maka perlu adanya perubahan pada proses pembelajaran. Tidak lagi dengan cara yang klasik (pembelajaran konvesional) yaitu pengajaran yang berpusat pada guru sehingga pembelajaran di kelas-kelas terlihat monoton, tetapi dapat dilakukan pembelajaran yang aktif, kreatif, inovatif, menyenangkan serta dapat mengatasi perbedaan individual siswa, sehingga pembelajaran dirasakan lebih bermakna bagi siswa.

Penggunaan model pembelajaran yang tepat dapat mendorong tumbuhnya rasa senang siswa terhadap suatu pelajaran, sehingga akan meningkatkan motivasi dalam mengerjakan tugas dan memberikan kemudahan bagi siswa untuk memahami pelajaran sehingga siswa dapat mencapai hasil belajar yang lebih baik. Diantara beberapa model pembelajaran yang ada, salah satunya adalah pembelajaran kooperatif (cooperative learning). Pembelajaran kooperatif digunakan untuk mewujudkan kegiatan belajar mengajar yang berpusat pada siswa (student oriented), terutama untuk mengatasi permasalahan yang ditemukan guru dalam mengaktifkan siswa, yang tidak dapat bekerja sama dengan orang lain, siswa yang agresif dan tidak peduli pada yang lain. Belajar kooperatif secara nyata semakin meningkatkan pengembangan sikap sosial dan belajar, ada empat elemen dasar dalam pembelajaran kooperatif, yaitu saling ketergantungan positif, interaksi tatap muka, akunbilitas individual, dan keterampilan menjalin hubungan interpersonal.

Sehingga dapat disimpulkan pembelajaran kooperatif merupakan peralatan yang kuat untuk meningkatkan kepercayaan diri sebagai seorang pembelajar atau pelajar pemecah masalah dan untuk memperkuat integrasi yang sebenarnya diantara berbagai macam siswa. Pembelajaran kooperatif merupakan salah satu alternatif pengajaran yang dapatr diterapkan di sekolah pada pengajaran di kelas, sehingga dapat meningkatkan kualitas pembelajaran.

Tujuan dari pembelajaran kooperatif adalah menciptakan situasi di mana keberhasilan individual ditentukan atau dipengaruhi oleh keberhasilan kelompoknya. Beberapa hasil penelitian menunjukan bahwa teknik-teknik pembelajaran kooperatif lebih banyak meningkatkan hasil belajar daripada pengalaman pembelajaran tradisional. Salah satu metode yang digunakan dalam belajar Matematika adalah penerapan model pembelajaran kooperatif tipe Numbered Heads Together (NHT).

NHT adalah model pembelajaran yang dikembangkan untuk melibatkan banyak siswa dalam menelaah materi yang tercakup dalam suatu pelajaran dan mengukur pemahaman mereka terhadap materi pembelajaran tersebut. Kelebihan model pembelajaran NHT diantaranya dapat meningkatkan prestasi belajar siswa, mengembangkan rasa ingin tahu, meningkatkan rasa percaya diri, mengembangkan rasa saling memiliki dan mengembangkan keterampilan untuk masa depan.

Muhsetyo (2008: 1.5) menyatakan pembelajaran matematika adalah proses pemberian pengalaman belajar kepada peserta didik melalui serangkaian kegiatan yang terencana sehingga peserta didik memperoleh kompetensi tentang materi yang dipelajari. Aisyah (2007: 4) Pembelajaran matematika dimaksudkan sebagai proses yang sengaja dirancang dengan tujuan untuk menciptakan suasana lingkungan (kelas atau sekolah) yang memungkinkan kegiatan siswa belajar matematika di sekolah. (Thobrani, 2016: 35) Pembelajaran merupakan upaya sengaja dan bertujuan yang berfokus kepada kepentingan, karakteristik, dan kondisi orang lain agar peserta didik dapat belajar dengan efektif dan efisien. Istilah ini merupakan paradigma baru yang menekankan pada prinsip keragaman peserta didik atau pembelajaran (learner).Pembelajaran adalah proses interaksi peserta didik dengan pendidikan dan sumber belajar pada suatu lingkungan belajar. Pembelajaran merupakan bantuan yang diberikan pendidik agar dapat terjadi proses pemerolehan ilmu dan pengetahuan, serta pembentukan sikap dan kepercayaan pada peserta didik, dengan kata lain, pembelajaran adalah proses untuk memproses peserta didik agar dapat belajar dengan baik (Muhibbin, 2011).

Biggs (1985) dalam (Sugihartono, 2006: 88) membagi konsep pembelajaran dalam tiga pengertian, antara lain: 
a. Pembelajaran dalam pengertian kuantitatif, secara kuantitatif pembelajaran berarti penularan pengetahuan dari guru kepada murid. Dalam hal ini guru dituntut untuk menguasai pengetahuan yang dimiliki sehingga dapat menyampaikannya kepada siswa dengan sebaik-baiknya.

b. Pembelajaran dalam pengertian institusonal, secara institusional pembelajaran berarti penataan segala kemampuan mengajar sehingga dapat berjalan efisien. Dalam pengertian ini guru dituntut untuk selalu siap mengadaptasikan berbagai teknik mengajar untuk bermacam-macam siswa ynag memiliki berbagai perbedaan individual.

c. Pembelajaran dalam pengertian kualitatif, secara kualitatif pembelajaran berarti upaya guru untuk memudahkan kegiatan belajar siswa. Dalam pengertian ini peran guru dalam pembelajran tidak sekedar memberikan pengetahuan kepada siswa, tetapi juga melibatkan siswa dalam aktivitas belajar yang efektif dan efisien.

Hasil belajar adalah kemampuan yang di peroleh anak setelah melalui kegiatan belajar Abdurrahman (dalam Asep Jihad dan Abdul Haris, 2013: 14). Belajar itu sendiri merupakan suatu proses dari seseorang yang berusaha untuk memperoleh suatu bentuk perubahan perilaku yang relatif menetap. Dalam kegiatan pembelajaran atau kegiatan intruksional, biasanya guru menetapkan tujuan belajar. Siswa yang berhasil dalam belajar adalah yang berhasil mencapai tujuan-tujuan pembelajaran atau tujuan intruksioanal.Menurut Bloom tiga ranah (domain) hasil belajar, yaitu kognitif, efektif dan pisikomotor. Menurut A.J. Romizowski hasil belajar merupakan keluaran (otputs) dari suatu sistem pemrosesan masukan (input). Masukan dari sistem tersebut berupa bermacam-macam informasi sedangkan keluarnya adalah perbuatan atau kinerja (performance) (Jihad, 2013:14).

Menurut Bloom (dalam Hendriana, 2014:68), kemampuan-kemampuan yang termasuk dalam domain kognitif dikategorikan dalam enam jenjang kemampuan yaitu :

a. Hafalan (C1)

Jenjang hafalan (ingatan) adalah kemampuan memanggil kembali pengetahuan dan informasi relevan yang telah tersimpan dalam memori jangka panjang.

b. Pemahaman (C2)

Jenjang pemahaman kemampuan membangun arti dari pesan-pesan pembelajaran, baik secara lisan, tulisan, ataupun melalui komunikasi grafis.

c. Aplikasi (C3)

Jenjang aplikasi dalah kemampuan menggunakan prinsip atau metode pada situasi yang baru.

d. Analisis (C4)

Jenjang analisis adalah kemampuan menguraikan materi ke dalam bagianbagian dan menentukan hubungan antara bagian serta menghubungkannya dengan keseluruhan bagian.

e. Evaluasi (C5)

Jenjang evaluasi adalah kemampuan membuat pertimbangan berdasarkan kriteria dan standar tertentu.

f. Kreatifitas (C6)

Jenjang kreatifitas adalah mencakup kemampuan untuk melahirkan aneka pola gerak-gerik yang baru, seluruhnya atas dasar prakarsa dan inisiatif sendiri.

Poerwadarminta (2003: 766) mengemukakan bahwa hasil belajar adalah hasil dari suatu kegiatan yang telah di lakukan atau dikerjakan oleh siswa. Sejalan dengan pendapat tersebut, Nasution (2006:21) mengemukakan bahwa hasil belajar merupakan interaksi secara aktif dan positif dengan lingkungan belajarnya.

Sudjana (dalam Asnany 2014: 16) mengatakan hasil belajar adalah hasil yang di capai oleh seseorang siswa dipengaruhi oleh dua faktor dari dalam diri siswa itu dan faktor yang datang dari luar diri siswa atau faktor lingkungan. Faktor kemampuan besar sekali pengaruhnya terhadap hasil belajar yang dicapai. Hasil belajar yang baik haruslah bersifat menyeluruh, artinya bukan sekedar penguasaan pengetahuan semata-mata tetapi juga nampak dalam perubahan sikap dan tingkah laku secara terpadu.

Untuk memperoleh hasil belajar, dilakukan evaluasi atau penilaian yang merupakan tindak lanjut atau cara untuk mengukur tingkat penguasan siswa. Kemajuan prestasi belajar siswa tidak saja diukur dari tingkat penguasan ilmu pengetahuan tetapi juga 
sikap dan keterampilan. Dengan demikian penilain hasil belajar siswa mencakup segala hal yang dipelajari di sekolah, baik itu menyangkut pengetahuan, sikap dan keterampilan (Asep Jihad dan Abdul Haris, 2013:15).

Dengan demikian dapat disimpulkan bahwa hasil belajar adalah hasil usaha belajar yang dicapai setelah ia melakukan kegiatan tersebut terhadap suatu bidang tertentu. Dimana hasil tersebut ditentukan setelah melakukan suatu tes pada bidang studi tertentu. Hasil belajar yang dihasilkan oleh siswa membawa perubahan-perubahan kemampuan pada aspek pengetahuan, pemahaman, keterampilan dan sikap. Adanya perubahan itu tampak dalam prestasi belajar yang ditunjukkan oleh siswa terhadap pertanyaan dan tugas yang diberikan oleh guru mata pelajaran.

Pembelajaran kooperatif dibangun atas dasar teori konstruktivis sosial dari vigotsky yang menyatakan bahwa pengetahuan dibangun melalui proses interaksi siswa dengan anggota komunitasnya yang lebih berkompeten. Interaksi sosial akan dapat menciptakan terjadinya pentrasferan informasi pada individu siswa, sehingga siswa mampu melakukan dan menumbuhkan keinginan belajar, serta dapat berpengaruh positif terhadap motivasi dan hasil belajarnya. Pembelajaran kooperatif juga berpengaruh pada penghargaan diri, perbaikan sikap terhadap mata pelajaran, teman sebaya, sekolah, serta gurunya, dan lebih terdorong untuk belajar dan berpikir ( Marsi, 2014:5).

Pembelajaran kooperatif merupakan model pembelajaran yang mengutamakan adanya kerja sama, yakni kerja sama antar siswa dalam kelompok untuk mencapai tujuan pembelajaran. Para siswa dibagi menjadi kelompok-kelompok kecil dan diarahkan untuk mempelajarinya materi pelajaran yang telah ditentukan Johnson (dalam Asnany, 2014:19).Pembelajaran kooperatif (cooperatif learning) adalah model pembelajaran dimana siswa dibiarkan belajar dalam kelompok, saling menguatkan, mendalami, dan bekarja sama untuk semakin menguasai bahan/ materi pelajaran (Suparno, 2007:134).

Pembelajaran kooperatif berbeda dengan strategi pembelajaran yang lain. Perbedaan tersebut dapat dilihat dari proses pembelajaran yang lebih menekankan kepada proses kerjasama antar kelompok (Sanjaya, 2006: 242).Berdasarkan beberapa pendapat tersebut, dapat disimpulkan bahwa model kooperatif adalah model pembelajaran yang mengutamakan adanya kerja sama dibangun melalui proses interaksi siswa dengan anggota komunitasnya yang lebih berkompeten yang mendorong peserta didik aktif menemukan sendiri pengetahuan melalui keterampilan proses.

NHT merupakan salah satu dari strategi pembelajaran kooperatif. Model pembelajaran ini dikembangkan oleh Spenser Kagan. Model NHT mengacu pada belajar kelompok siswa, masing-masing anggota memiliki bagian tugas (pertanyaan) dengan nomor yang berbeda-beda. Misalkan, dalam pembelajaran reproduksi yang mempelajari proses perkembangbiakan tumbuhan dan hewan lebih mengacu pada interaksi sosial sehingga pembelajaran NHT dapat meningkatkan hubungan sosial antarsiswa.

Setiap siswa mendapatkan kesempatan sama untuk menunjang timnya guna memperoleh nilai yang maksimal sehingga termotivasi untuk belajar. Dengan demikian setiap individu merasa mendapat tugas dan tanggung jawab sehingga tujuan pembelajaran dapat tercapai.Model pembelajaran kooperatif tipe NHT merupakan suatu model pembelajaran berkelompok yang setiap anggota kelompoknya bertanggung jawab atas tugas kelompoknya, sehingga tidak ada pemisahan antar siswa yang satu dan siswa yang lain dalam satu kelompok untuk saling member dan menerima antara satu dengan yang lainnya' (Shoimin: 107).

Menurut Shoimin, 2016: 109 kelebihan dan kekurangan model pembelajaran kooperatif tipe numbered heads together (NHT) yaitu:

a. Kelebihan model pembelajaran kooperatif Tipe Numbered Heads Together (NHT)

1. Setiap murid menjadi siap.

2. Dapat melakukan diskusi dengan sungguh-sungguh.

3. Murid yang pandai dapat mengajari murid yang kurang pandai.

4. Terjadi interaksi secara intens antarsiswa dalam menjawab soal.

5. Tidak ada murid yang mendominasi dalam kelompok karena ada nomor yang membatasi.

b. Kekurangan model pembelajaran kooperatif Tipe Numbered Heads Together (NHT)

1. Tidak terlalu cocok diterapkan dalam jumlah siswa yang banyak 
karena membutuhkan waktu yang lama.

2. Tidak semua anggota kelompok dipanggil oleh guru karena kemungkinan waktu yang terbatas.

Model pembelajaran konvensional merupakan pembelajaran yang biasa digunakan untuk menyampaikan materi dalam kelas. pembelajaran konvensional merupakan pembelajaran yang mengacu pada guru atau teacher center, dimana guru adalah tokoh utama dalam pembelajaran. Penggunaan pembelajaran ini dianggap praktis, karena hanya menggunakan metode-metode sederhana.

Pembelajaran konvensional menurut Djamarah (2006), "identik dengan metode ceramah, tanya jawab dan pemberian tugas". Sebabnya pembelajaran konvensional secara langsung menjadikan siswa pasif dalam pembelajaran. Metode ceramah adalah sebuah metode yang boleh dikatakan metode tradisional, karena sejak dulu metode ini telah dipergunakan sebagai alat komunikasi lisan antara guru dengan anak didik dalam proses belajar mengajar.

Menurut Sanjaya (2006: 179) model pembelajaran konvensional merupakan model pembelajaran yang biasa diterapkan guru dalam melaksanakan proses pembelajaran.

Tabel 1

Jumlah Siswa Dan Data Awal Pada Setiap Kelas

\begin{tabular}{|c|c|c|}
\hline Kelas & $\mathrm{VIII}_{1}$ & $\mathrm{VIII}_{2}$ \\
\hline Jumlah Siswa & 23 & 22 \\
\hline $\begin{array}{c}\text { Nilai Rata-rata Hasil } \\
\text { Belajar Matematika }\end{array}$ & 58,56 & 58,21 \\
\hline
\end{tabular}

Pengambilan sampel dalam penelitian ini dilakukan dengan menggunakan teknik total sampling. Teknik sampling ini dilakukan dengan pertimbangan dari salah satu guru matematika di SMP Negeri 2 Tongkuno yang menyarankan mengambil kelas VIII $_{1}$ sebagai kelas eksperimen, dalam penelitian ini hanya memiliki dua kelas dan berdasarkan hasil wawancara dengan pihak sekolah, semua kelas VIII, penyebaran kelas di SMP Negeri 2 Tongkuno adalah homogen (tidak ada tingkatan/strata) dimana penyebaran siswa di setiap kelas adalah heterogen, dari hasil proses pengacakan maka diperoleh kelas $\mathrm{VIII}_{1}$ sebagai kelas eksperimen.

Variabel yang digunakan dalam penelitian ini adalah:(a)variabel bebas adalah model pembelajaran kooperatif tipe Numbered
Pembelajaran konvensional yang dimaksud secara umum adalah pembelajaran dengan menggunakan metode yang biasa dilakukan oleh guru yaitu member materi melalui ceramah, latihan soal kemudian pemberian tugas. Dalam pembelajaran konvensional, guru memiliki peranan yang sangat penting karena pembelajaran yang berlangsung berpusat pada guru untuk menerangkan materi dari awal hingga akhir pelajaran.

\section{Metode}

Jenis penelitian yang digunakan dalam penelitian ini adalah eksperimen dengan menggunakan model pembelajaran kooperatif tipe NHT sebagai kelas eksperimen dan pembelajaran konvensional sebagai kelas kontrol. Penelitian ini akan dilaksanakan pada semester genap tahun ajaran 2017/2018 bertempat di SMPN 2 Tongkuno

Populasi dalam penelitian ini adalah seluruh siswa kelas VIII SMPN 2 Tongkuno yang terdaftar pada tahun ajaran 2017/2018 yang tersebar pada 2 kelas yaitu kelas $\mathrm{VIII}_{1}, \mathrm{VII}_{2}$. sebaran siswa kelas VIII SMPN 2 Tongkuno disajikan pada table 3.1 berikut.
Heads Together (NHT) (X) (b) variabel terikat adalah hasil belajar matematika siswa kelas VIII SMP Negeri 2 Tongkuno (Y). Definisi Operasional: (a)Model pembelajaran kooperatif tipe NHT diartikan sebagai suatu model pembelajaran yang mengacu pada belajar kelompok dengan menyajikan informasi pelajaran dimana siswa dibagi menjadi kelompok belajar yang beranggotakan 5 atau 6 orang yang pada prinsipnya siswa dapat menyerap, mencerna dan mengingat bahan pelajaran dengan baik dalam kegiatannya siswa dapat menjelaskan kembali materi tersebut.(b) Hasil belajar adalah tingkat keberhasilan yang dimiliki oleh siswa dalam kurun waktu tertentu setelah menerima pengalaman belajarnya. 
Tabel 2

The Posttes Only Control Group Design

\begin{tabular}{|c|c|c|c|}
\hline & Group & Perlakuan & Tes \\
\hline $\mathrm{R}$ & Eksperimen (E) & $\mathrm{X}$ & $\mathrm{Y}_{\mathrm{E}}$ \\
\hline $\mathrm{R}$ & Kontrol (K) & - & $\mathrm{Y}_{\mathrm{K}}$ \\
\hline
\end{tabular}

diajar dengan menggunakan model pembelajaran

Keterangan:

$\mathrm{X}$ : Perlakuan berupa penerapan model pembelajaran kooperatif tipe NHT

$\mathrm{Y}_{\mathrm{E}}$ : Hasil tes pada kelas eksperimen dengan model pembelajaran kooperatif tipe NHT

$\mathrm{Y}_{\mathrm{K}}$ : Hasil tes pada kelas kontrol dengan model pembelajaran konvensional

\section{R: Random}

Instrument penelitian merupakan alat pengumpul data dalam suatu penelitian yang dirancang sehingga menghasilkan data yang empiris. Instrument yang digunakan dalam penelitian ini berupa tes hasil belajar matematika. Tes hasil belajar dalam penelitian ini digunakan untuk mengukur hasil belajar matematika siswa pada kelas eksperimen yang

$$
r_{x y}=\frac{N \sum X Y-\left(\sum X\right)\left(\sum Y\right)}{\sqrt{\left\{N \sum X^{2}-\left(\sum X\right)^{2}\right\}\left\{N \sum Y^{2}-\left(\sum Y\right)^{2}\right\}}}
$$

Keterangan :

$r_{x y}=$ koefisien korelasi antara variabel $\mathrm{X}$ dengan variabel $\mathrm{Y}$

$\mathrm{X}=$ skor item

$\mathrm{Y}=$ skor total

$\mathrm{N}=$ jumlah subjek

Adapun kriteria pengujian sebagai

berikut:(a)Jika $r_{X Y} \geq r_{\text {tabel }}$ dengan $\alpha=0,05$

maka butir soal tersebut valid.(b)Jika $r_{X Y}<$

$r_{\text {tabel }}$ dengan $\alpha=0,05$ maka butir soal tersebut

tidak valid. Sedangkan untuk mengukur reliabilitas tes dalam penelitian ini digunakan rumus Alpha berikut (Arikunto, 2016: 122).

$$
r_{11}=\left(\frac{n}{n-1}\right)\left(1-\frac{\sum \sigma_{i}^{2}}{\sigma_{t}^{2}}\right)
$$

Keterangan :

$r_{11}=$ reliabilitas yang dicari

$n=$ banyak butir soal

$\sum \sigma_{i}^{2}=$ jumlah variansi skor tiap butir item/soal

$\sigma_{t}^{2}=$ variansi skor total

Untuk menentukan tinggi rendahnya reliabilitas sebuah tes menggunakan ketentuan yaitu:

$r_{11} \leq 0,20$ reliabilitas : sangat rendah

$0,20<r_{11} \leq 0,40$ reliabilitas : rendah $0,40<r_{11} \leq 0,70$ reliabilitas : sedang

$0,70<r_{11} \leq 0,90$ reliabilitas : tinggi

$0,90<r_{11} \leq 1,00$ reliabilitas : sangat tinggi

Pengumpulan data dalam penelitian ini

dilakukan dengan pemberian instrument penelitian berupa tes hasil belajar dalam bentuk essay kepada siswa. Setelah kegiatan pembelajaran, maka diadakan tes hasil belajar matematika pada kedua kelas untuk mengetahui hasil belajar matematika siswa kedua kelas tersebut.

Dalam penelitian ini digunakan dua teknik analisis statistik, yaitu teknik statistik deskriptif dan statistik inferensial. Statistik deskriptif dimaksudkan untuk mendeskripsikan atau menggambarkan variabel-variabel penelitian secara tunggal melalui mean (rata-rata), modus, median, standar deviasi (SD), varians, skor maksimum dan skor minimum, sedangan analisis inferensial digunakan untuk pengujian hipotesis penelitian dengan menggunakan uji-t dengan bantuanSPSS. Uji homogenitas varians dilakukan untuk mengetahui apakah data yang diperoleh mempunyai varians populasi yang sama atau tidak, maka di lakukan uji homogenitas varians dengan menggunakan rumus:

$F_{\text {hit }}=\frac{\text { Varians terbesar }}{\text { Varians terkecil }}$

(Sudjana, 2005: 50) 
Pengujian dilakukan pada $\alpha=0,05$ dengan kriteria pengujian adalah: Terima $\mathrm{H}_{0}$ jika $\mathrm{F}_{\text {hit }}<\mathrm{F}_{\text {tabel }}$ artinya varians kedua kelompok homogen. Data dalam penelitian ini setelah dilakukan uji normalitas dan uji homogenitas diperoleh bahwa data berdistribusi normal dan varians homogen, maka pengujian hipotesis yang digunakan adalah uji perbedaan dua ratarata atau statistik uji-t

$$
\mathrm{t}=
$$

(Sudjana, 2005:239)

Kreteria : jika $\mathrm{t}_{\text {hit }}<\mathrm{t}_{\text {tab }}$ pada $a$ (alfa) sebesar 0,05 maka $\mathrm{H}_{0}$ diterima. Dan jika $\mathrm{t}_{\text {hit }} \geq \mathrm{t}_{\text {tab }}$ maka $\mathrm{H}_{0}$ ditolak.

Varians gabungan, $\mathrm{S}$ dihitung dengan rumus :

$\mathrm{S}_{\mathrm{gab}}=\sqrt{\frac{\left(n_{1}-1\right) s_{1}^{2}+\left(n_{2}-1\right) s_{2}^{2}}{n_{1}+n_{2}-2}}$

(Sudjana 2005:239)

Keterangan :

$\overline{X_{1}}=$ Nilai rata-rata siswa kelompok NHT
$\overline{X_{2}}=$ Nilai rata-rata siswa kelompok kontrol

$S_{g a b}^{2}=$ varians gabungan

$\mathrm{S}_{\mathrm{gab}}=\sqrt{S_{\text {gab }}^{2}}=$ simpangan baku gabungan

$S_{1}^{2}=$ varians kelompok NHT

$S_{2}^{2}=$ varians kelompok kontrol

$\mathrm{n}_{1}=$ ukuran sampel kelompok NHT

$\mathrm{n}_{2}=$ ukuran sampel kelompok kontrol

\section{Hasil}

Analisis data merupakan bagian yang sangat penting dalam suatu penelitian. Analisis data dan pembahasan dalam penelitian eksperimen ini terdiri dari analisis deskriptif dan analisis inferensial dengan menggunakan bantuan aplikasi SPSS Ver.16. Pembahasan ini menghubungkan hasil analisis antara variabel bebas terhadap variabel terikat. Soal uji coba instrument berjumlah 6 nomor soal dalam bentuk essay dan dilakukan uji coba di kelas IX SMP Negeri 2 Tongkuno. Adapun hasil analisis validitas uji coba instrumen dapat dilihat pada Tabel 3

Tabel 3

Hasil Analisis Validitas Tes Hasil Belajar Matematika Siswa

\begin{tabular}{|c|c|c|}
\hline No soal & Indeks validitas & Keterangan \\
\hline 1. & 0,46 & Valid \\
\hline 2. & 0,78 & Valid \\
\hline 3. & 0,76 & Valid \\
\hline 4. & 0,62 & Valid \\
\hline 5. & 0,52 & Valid \\
\hline 6. & 0,52 & Valid \\
\hline
\end{tabular}

Berdasarkan tabel 3 diperoleh bahwa jika uji validitas instrumen dilakukan dengan membandingkan hasil perhitungan $r_{x y}$ dengan $r_{\text {tabel }}$ pada taraf signifikansi $5 \%(\alpha=0,05)$. Jika hasil perhitungan $r_{x y}>r_{\text {tabel }}$ maka butir soal tersebut valid, namun jika hasil perhitungan

Tabel 4

$r_{x y} \leq r_{\text {tabel }}$ maka butir soal tersebut dinyatakan tidak valid. Dan diperoleh $r_{\text {tabel }} \quad 0,35$ ini berarti semua soal tes valid. Sedangkan untuk hasil analisis reliabilitas tes hasil belajar matematika siswa, dapat dilihat pada Tabel 4

\section{Hasil Analisis Realibilitas Uji Coba Instrument Reliability Statistics}

\begin{tabular}{|c|r|r|}
\hline $\begin{array}{c}\text { Cronbach's } \\
\text { Alpha }\end{array}$ & $\begin{array}{c}\text { Cronbach's Alpha Based on } \\
\text { Standardized Items }\end{array}$ & N of Items \\
\hline, 711 &, 719 & 6 \\
\hline
\end{tabular}

Berdasarkan Tabel 4 diperoleh koefisien reliabilitasnya sebesar 0,711 yang dapat diartikan dalam kategori tinggi. Hal ini berarti bahwa tes ini dapat diandalkan untuk mengukur pengolahan data dengan menggunakan analisis deksriptif, diperoleh nilai siswa untuk masingmasing kelas yaitu kelas yang diberi perlakuan dengan menggunakan model pembelajaran hasil belajar matematika siswa. Berdasarkan kooperatif tipe NHT dan siswa yang diajar 
dengan menggunakan model pembelajaran konvensional. Hasil analisis deskriptif data hasil belajar matematika siswa kelas eksperimen dan kelas kontrol menggunakan bantuan aplikasi IBM SPSS Statistic.

Tabel 5

Deskripsi Hasil Belajar Matematika Siswa Kelas Eksperimen dan Kelas Kontrol Descriptive Statistics

\begin{tabular}{|l|l|r|r|r|r|r|}
\hline & N & Minimum & Maximum & Mean & Std. Deviation & Variance \\
\hline K_EKSPERIMEN & 23 & 62,50 & 87,50 & 75,4130 & 5,83417 & 34,038 \\
K_KONTROL & 22 & 50,00 & 77,50 & 65,5682 & 8,34280 & 69,602 \\
Valid N (listwise) & 22 & & & & & \\
\hline
\end{tabular}

Berdasarkan Tabel 5 terlihat bahwa nilai minimum dari kedua kelas berbeda, nilai 62,50 untuk kelas eksperimen, dan nilai 50,00 untuk kelas kontrol. Begitu pula yang terjadi dengan nilai maksimumnya, yaitu nilai 87,50 untuk kelas eksperimen, dan nilai 77,50 untuk kelas kontrol. Nilai rata-rata (mean) yang terbesar diperoleh pada kelas eksperimen yaitu 75,41, sedangkan untuk kelas kontrol nilai rata-rata kelas yang diperoleh yaitu 65,56 . Nilai standar deviasi (Std. Devation) untuk kelas eksperimen adalah 5,83 dan untuk kelas kontrol adalah 8,34. Sedangkan nilai varians adalah kuadrat dari nilai standar deviasi.

Tahap selanjutnya dalam analisis data adalah analisis inverensial. Melalui analisis inverensial kita dapat mengetahui apakah hipotesis dalam peneletian ini diterima atau ditolak. Dalam analisis inverensial, terdapat beberapa tahap analisis yang menjadi prasyarat untuk melakukan analisis uji hipotesis yaitu hasil analisis uji normalitas data dan analisis uji homogenitas data. Analisis uji normalitas data dimaksudkan untuk mengetahui apakah data hasil belajar yang diperoleh berdistribusi normal atau tidak, sedangkan analisis homogenitas dimaksudkan untuk mengetahui apakah kedua kelompok data memiliki varians yang homogen atau tidak. Setalah melalui uji normalitas dan homogenitas data maka dilanjutkan dengan uji hipotesis.

Uji normalitas digunakan untuk menguji data hasil belajar matematika pada kelas eksperimen dan kelas kontrol berdistribusi normal atau tidak, digunakan statistik Kolmogrof-Smirnov, dengan menggunakan bantuan aplikasi SPSS. Hasil perhitungan dapat disajikan dalam Tabel 6

Tabel 6

Hasil Analisis Statistik Uji Normalitas Data Hasil Belajar Matematika Siswa Pada Kelas Eksperimen dan Kelas Kontrol

One-Sample Kolmogorov-Smirnov Test

\begin{tabular}{|c|c|c|c|}
\hline & & K_EKSPERIMEN & K_KONTROL \\
\hline & 23 & 22 \\
\hline \multirow{2}{*}{$\begin{array}{l}\text { N } \\
\text { Normal } \\
\text { Parameters } \\
\text { b }\end{array}$} & Mean & 75,4130 & 65,5682 \\
\hline & Std. Deviation & 5,83417 & 8,34280 \\
\hline Most & Absolute & , 118 & , 157 \\
\hline Extreme & Positive & ,085 & , 106 \\
\hline Differences & Negative &,- 118 &,- 157 \\
\hline Kolmogorov- & Smirnov Z &, 566 &, 736 \\
\hline Asymp. Sig. ( & (2-tailed) & ,906 & ,651 \\
\hline
\end{tabular}

a. Test distribution is Normal.

Sumber: Data Primer Diolah dengan SPSS/PC Ver.16

Pengambilan keputusan untuk normalitas data adalah sebagai berikut:

$\mathrm{H}_{0}$ : Data berdistribusi normal

$\mathrm{H}_{1}$ : Data tidak berdistribusi normal
Dengan kriteria pengujian :

$\mathrm{H}_{0}$ diterima jika nilai Asymp. Sig. $>\alpha(0,05)$

Berdasarkan hasil analisis perhitungan uji normalitas diperoleh untuk kelas eksperimen nilai Asymp. Sig. (2-tailed) $=0,906>0,05=\alpha$ maka $\mathrm{H}_{0}$ diterima. Hal ini berarti bahwa data hasil belajar matematika siswa pada kelas 
eksperimen berdistribusi normal. Sedangkan untuk kelas kontrol diperoleh nilai Asymp. Sig. (2-tailed) $=0,651>0,05=\alpha$ maka $\mathrm{H}_{0}$ diterima. Hal ini berarti bahwa data hasil belajar matematika siswa pada kelas kontrol berdistribusi normal.

Uji homogenitas digunakan untuk mengetahui apakah data mempunyai varians yang sama (homogen) atau tidak. Uji homogenitas yang digunakan adalah Uji Fisher (Uji F). Kriteria pengujian yang digunakan yaitu kedua kelas dikatakan homogen apabila $\mathrm{F}_{\text {hitung }} \leq$ $\mathrm{F}_{\text {tabel }}$ diukur sesuai dengan taraf signifikansi dan tingkat kepercayaan tertentu. Dari hasil perhitungan data tes pada kelas eksperimen yang berjumlah 23 siswa dengan varians 34,038 dan kelas kontrol yang berjumlah 22 siswa dengan varians 69,602, maka diperoleh $\mathrm{F}_{\text {hitung }}=2,04$ dan $\mathrm{F}_{\text {tabel }}=2,07$ pada taraf signifikansi $\alpha=0,05$ dengan derajat kebebasan pembilang 21 dan derajat kebebasan penyebut 22. Karena $\mathrm{F}_{\text {hitung }}<$ $\mathrm{F}_{\text {tabel }}(2,04<2,07)$ maka $\mathrm{H}_{0}$ diterima yang artinya kedua kelas sampel memiliki varians yang homogen. Secara ringkas, hasil pengujian homogenitas dapat dilihat pada tabel berikut:

Tabel 7

Hasil Perhitungan Uji Homogenitas

\begin{tabular}{|c|c|c|c|c|c|}
\hline & $\mathbf{N}$ & $\begin{array}{c}\text { Varians } \\
\left(\mathbf{S}^{\mathbf{2}}\right)\end{array}$ & \multicolumn{2}{|c|}{$\mathbf{F}(\mathbf{a})=\mathbf{0 , 0 5}$} & Kesimpulan \\
\hline Eksperimen & 23 & 34,038 & Hitung & Tabel & $\begin{array}{c}\text { Varians } \\
\text { homogeny }\end{array}$ \\
\hline Kontrol & 22 & 69,602 & 2,04 & 2,07 & \\
\hline
\end{tabular}

Data yang diperoleh berdistribusi normal, dan memiliki varians yang homogen, maka untuk menguji tes kemampuan hasil belajar matematika siswa yang diajar dengan menggunakan model pembelajaran kooperatif tipeNHT dan siswa yang diajar dengan pembelajaran konvensional, digunakan uji $t$.
Berdasarkan hasil perhitungan, diperoleh $\mathrm{t}_{\text {hitung }}=4,61$, sedangkan pada taraf signifikan $\alpha=$ 0,05 dan derajat kebebasan $(d k)=43$ diperoleh $\mathrm{t}_{\text {tabel }}=1,681$. Untuk lebih jelasnya hasil hipotesis dengan menggunakan uji $t$ pada kelas eksperimen dan kelas kontrol dapat dilihat pada Tabel 8 berikut.

Tabel 8

Rekapitulasi hasil perhitungan uji $t$

\begin{tabular}{|c|c|c|}
\hline Statistik & Kelas Eksperimen & Kelas Kontrol \\
\hline Rata-rata & 75,4130 & 65,5682 \\
\hline Varians & 34,038 & 69,602 \\
\hline Sgabungan & \multicolumn{2}{|c|}{7,16} \\
\hline THitung & \multicolumn{2}{|c|}{4,61} \\
\hline TTabel & \multicolumn{2}{|c|}{1,681} \\
\hline Kesimpulan & Tolak $\mathrm{H}_{0}$ \\
\hline
\end{tabular}

Hasil perhitungan dari tabel di atas, menunjukkan bahwa $\mathrm{t}_{\text {hitung }}>\mathrm{t}_{\text {tabel }} \quad(4,61>$ 1,681) maka dapat disimpulkan bahwa $\mathrm{H}_{0}$ ditolak, hal ini berarti rata-rata hasil belajar matematika siswa yang diajar dengan model pembelajaran kooperatif tipe NHT, lebih baik dari hasil belajar yang diajar dengan menggunakan model pembelajaran konvensional.

\section{Pembahasan}

Penelitian ini dimaksudkan untuk mengetahui perbedaan hasil belajar matematika siswa kelas VIII Semester ganjil SMP Negeri 2 Tongkuno pada materi pola bilangan. Untuk mengetahui perbedaan hasil belajar tersebut, maka diambil dua kelas sebagai kelompok sampel yaitu kelas eksperimen dan kelas kontrol, di mana kedua kelas memiliki kemampuan matematika yang relatif sama. Masing-masing kelas diberi perlakuan berbeda. Kelas eksperimen diberi perlakuan dengan menggunakan model pembelajaran kooperatif tipe NHT, sedangkan kelas kontrol diberikan perlakuan dengan menggunakan model pembelajaran konvensional. Kedua kelas diberi 
materi yang sama yakni materi pola bilangan dengan urutan materi yang sama. Berdasarkan uraian analisis data hasil penelitian dan pengujian hipotesis di atas, berikut ini dikemukakan pembahasan terhadap beberapa temuan sehubungan dengan hasil belajar matematika berdasarkan pembelajaran yang digunakan.

\section{(1)Deskripsi}

Pelaksanaan

PembelajaranPada penelitian ini, peneliti menggunakan dua kelas, yakni kelas $\mathrm{VIII}_{1}$ sebagai kelas eksperimen dan kelas $\mathrm{VIII}_{2}$ sebagai kelas kontrol. Kelas eksperimen adalah kelas yang diajar dengan model pembelajaran kooperatif tipe NHT dan kelas kontrol adalah kelas yang diajar dengan menggunakan model pembelajaran konvensional. Pada kedua kelas diberi perlakuan, dan setelah diberi perlakuan diberikan tes hasil belajar matematika.

Total pertemuan pada penelitian ini adalah 4 kali pertemuan baik pada kelas eksperimen maupun pada kelas kontrol, yakni untuk membahas materi pembelajaran dan 1 kali pertemuan untuk pelaksanaan pembelajaran instrument penelitian (instrument hasil belajar) dilakukan pada kelas eksperimen maupun pada kelas kontrol. Kedua kelas diberi materi yang sama yakni materi pola bilangan dengan urutan materi yang sama. Model pembelajaran yang digunakan pada kelas eksperimen adalah model pembelajaran kooperatif tipe NHT yang terdiri dari beberapa langkah pembelajaran dimana pembelajaran kooperatif tipe NHT merupakan model pembelajaran kelompok. Pembelajaran kooperatif tipe NHT mengutamakan adanya kerja sama dalam satu kelompok untuk mencapai tujuan pembelajaran. Dalam pembelajaran ini selain terjadi interaksi antara guru dan siswa juga interaksi antara siswa dengan siswa, khususnya siswa yang mengalami kesulitan belajar cenderung lebih berani bertanya kepada teman-temannya dari pada guru, bahkan ada pula siswa yang justru belajar lebih banyak karena harus mengajar temanya.

Pada pertemuan pertama di kelas eksperimen, pertama-tama dilakukan kegiatan pendahuluan yang meliputi penyiapan logistik, pemberian apersepsi, penyampaian tujuan pembelajaran, dan pemberian motivasi. Setelah kegiatan pendahuluan dilakukan, kemudian dilanjutkan pada kegiatan inti yakni, pemberian materi secara singkat dan jelas, kemudian dilakukan pembagian kelompok, dengan setiap kelompok beranggotakan 5-6 orang siswa dimana masing-masing siswa memiliki nomor. Setelah pembagian kelompok, siswa diarahkan untuk berkumpul dengan kelompoknya masingmasing. Setalah itu setiap kelompok diberikan LKPD untuk dikejakan dengan teman kelomponya. Pada tahap ini, guru berperan memberi pengarahan dan bimbingan kepada siswa melalui penjelasan atau pertanyaan yang mengarah pada penyelesaian masalah bila diminta langsung oleh siswa. Setelah semua kelompok telah selesai mengerjakan LKPD yang telah diberikan sesuai dengan jangka waktu yang ditentukan, beberapa siswa dipilih mewakili kelompoknya untuk tampil di depan kelas mempresentasikan hasil kerja kelompoknya untuk ditanggapi oleh kelompok lain. Guru berperan memandu jalanya diskusi, meluruskan jika ada jawaban siswa yang keliru dan membantu siswa dalam mengambil kesimpulan alterntaif jawaban yang paling benar. Diakhir pertemuan, guru membimbing siswa membuat kesimpulan dari materi yang telah dipelajari.

Menerapkan model pembelajaran kooperatif tipe NHT dalam pembelajaran tentunya bukan hal yang mudah. Banyak kendala-kendala yang di hadapi oleh guru dan siswa sehingga menghambat kegiatan pembelajaran. Pada saat pembelajaran melalui tahapan-tahapan model pembelajaran kooperatif tipe NHT guru kesulitan dalam mengorganisir waktu. Guru dan siswa seharusnya konsisten dalam pengaturan waktu sesuai dengan perhitungan alokasi waktu dalam RPP. Kenyataanya dalam setiap tahapan-tahapan pembelajaran selalu mengalami penguluran waktu sehingga ada beberapa tahapan yang tidak sempat dilaksanakan karena waktu yang terbatas. Inilah salah satu hal yang menjadikan banyak peneliti-peneliti sebelumnya yang menyimpulkan bahwa salah satu kelemahan model pembelajaran kooperatif tipe NHT adalah memerlukan waktu yang relatif lebih lama dibandingkan dengan model-model pembelajaran lainnya.

Berdasarkan pertemuan pertama pada kelas eksperimen, peneliti mengalami hambatan dimana siswa belum terbiasa dengan model pembelajaran yang baru yang diterapkan di dalam kelas mereka. Pada saat pembentukan kelompok tersebut, setiap siswa belum terbiasa untuk beradaptasi dengan teman kelompoknya yang baru serta belum terbiasa untuk bekerja 
sama dalam kelompok dalam menyelesaikan masalah yang diberikan oleh guru pada saat pemberian LKPD. Pelaksanaan pembelajaran pada pertemuan kedua sampai pertemuan keempat mengalami peningkatan yang baik, dimana siswa maupun guru perlahan-lahan sudah bisa menyesuaikan dengan model pembelajaran yang digunakan pada saat pembelajaran berlangsung yakni model pembelajaran kooperatif tipe NHT, dengan sebelumnya telah merefleksi kekurangan pada saat kegiatan pembelajaran pertemuan pertama.

Berdasarkan hasil pengamatan pada kelas eksperimen pada pertemuan pertama menunjukan sebagian besar siswa sudah memiliki sikap dapat dipercaya, teliti, menghargai, tanggung jawab individu, tanggung jawab sosial, adil dan peduli. Dari setiap pembelajaran juga diketahui beberapa siswa sudah memiliki keterampilan sosial yang baik, dimana mereka mau bekerja sama dalam pembelajaran kelompok walaupun ada sebagian siswa kurang aktif dalam kelompoknya, namun hal ini dapat diatasi dengan baik karena pada dasarnya karakter siswa mau mendengarkan arahan dari guru. Nasehat dan bimbingan dari guru membuat sebagian siswa menunjukan peningkatan yang baik dalam perilaku dan keterampilan sosial mereka, diantaranya siswa yang tadinya kurang memiliki rasa tanggung jawab terhadap kelompoknya, telah menunjukan rasa tanggung jawab mereka berkat arahan dan masukan dari gurunya. Siswa juga lebih termotivasi untuk belajar dalam kelompok. Sebagian besar siswa juga telah dapat memberikan ide atau pendapat yang baik dalam proses pembelajaran kelompok.

Pembelajaran yang dilaksanakan pada kelas kontrol $\left(\mathrm{VIII}_{2}\right)$ adalah pembelajaran konvensional. Metode yang digunakan adalah ceramah, tanya jawab, mengerjakan soal latihan dan pemberian tugas. Dalam pembelajaran konvensioanal, guru menjelaskan materi secara terurut kemudian siswa diberi kesempatan untuk mencatat. Selanjutnya guru memberikan beberapa contoh soal dan menjelaskan cara penyelesainya, kemudian guru memberikan solasoal latihan untuk dikerjakan dibuku latihan. Setelah selesai mengerjakan soal, beberapa siswa diminta untuk mengerjakan di papan tulis. Guru memberikan kesempatan kepada siswa untuk bertanya jika ada yang belum dimengerti atau dipahami. Di akhir pembelajaran, guru menegaskan kembali tentang materi yang telah dipelajari kemudian memberikan PR atau tugas rumah.

(2)Perbedaan Hasil Belajar Matematika Siswa yang diajar dengan Model Pembelajaran Kooperatif Tipe Number Heads Together (NHT) dan Siswa yang diajar dengan Model Pembelajaran Konvensional. Data hasil belajar matematika diperoleh melalui tes hasil belajar matematika. Tes tersebut diberikan kepada siswa yang diajar dikelas eksperimen dan kelas kontrol setelah diberikan perlakuan keduanya. Setelah dilaksanakan pembelajaran pada kelas eksperimen dengan model pembelajaran kooperatif tipe NHT dan kelas kontrol dengan model pembelajaran konvensional, diperoleh data hasil belajar matematika siswa kedua kelas. Data tersebut diolah dan diperoleh nilai hasil belajar matematika pada kelas eksperimen dan kelas kontrol. Data inilah yang dijadikan sebagai data dalam penelitian ini.

Berdasarkan hasil analisis deskriptif dari data yang diperoleh melalui tes hasil belajar matematika siswa diperoleh nilai rata-rata hasil belajar matematika siswa pada kelas eksperimen sebesar 75,41 sedangkan pada kelas kontrol sebesar 65,56. Hal ini menunjukan bahwa ratarata hasil belajar matematika siswa pada kelas eksperimen lebih tinggi dari pada rata-rata hasil belajar siswa pada kelas kontrol. Rata-rata sebesar 75,41 menunjukan bahwa nilai terbesar mewakili 23 orang siswa pada kelas eksperimen. Begitu pula rata-rata sebesar 65,56 menunjukkan bahwa nilai tersebut mewakili nilai 22 siswa pada kelas kontrol. Hal ini mengindikasikan dari segi rata-rata hasil belajar matematika siswa, pembelajaran dengan menggunakan model pembelajaran kooperatif tipe NHT lebih baik dari pada siswa yang diajar dengan model pembelajaran konvensional.

Berdasarkan uji Kolmogorov- Smirnov diperoleh untuk data hasil belajar matematika siswa pada kelas eksperimen dan kelas kontrol berdistribusi normal. Selanjutnya berdasarkan uji homogenitas varians data hasil belajar matematika siswa kelas eksperimen dan kelas kontrol dengan menggunakana program SPPS diperoleh bahwa data hasil belajar matematika kedua kelompok mempunyai varians yang homogen.

Uji hasil hipotesis perbedaan rata-rata hasil belajar matematika kelas eksperimen dan kontrol menunjukkan bahwa rata-rata hasil 
belajar matematika kelas eksperimen dan kelas kontrol berbeda secara nyata, dimana sebelumnya telah dilakukan uji normalitas dan homogenitas data. Uji hasil hipotesis perbedaan rata-rata hasil belajar matematika kelas eksperimen dan kontrol menunjukkan bahwa rata-rata hasil belajar matematika kelas eksperimen dan kelas kontrol berbeda secara nyata, dimana sebelumnya telah dilakukan uji normalitas dan homogenitas data. Berdasarkan hasil uji $\mathrm{t}$ di peroleh $\mathrm{t}_{\text {hitung }}>\mathrm{t}_{\text {tabel }}(4,61>1,681)$ yang berarti $\mathrm{H}_{0}$ ditolak. Dengan kata lain, terdapat pengaruh yang signifikan hasil belajar matematika siswa yang diajar dengan model pembelajaran kooperatif tipe NHT dan model pembelajaran konvensional.

\section{Simpulan dan Saran}

\section{Simpulan}

Berdasarkan hasil penelitian, penulis menyimpulkan bahwa:

1. Hasil belajar matematika siswa kelas VIII $_{1}$ yang diajar dengan model pembelajaran kooperatif tipe NHT pada materi pola bilangan dengan nilai rata-rata 75,41 , untuk nilai tertinggi 87,50 dan nilai terendah adalah 62,50

2. Hasil belajar matematika siswa kelas $\mathrm{VIII}_{2}$ yang diajar dengan model pembelajaran konvensional pada materi pola bilangan termaksud dalam kategori sedang dengan nilai rata-rata 65,56 untuk nilai tertinggi 77,50 , dan nilai terendah adalah 50,00.

3. Model pembelajaran kooperatif tipe NHT berpengaruh terhadap hasil belajar matematika siswa kelas VIII SMP Negeri 2 Tongkuno.

\section{B. Saran}

Saran yang dapat diberikan oleh penulis bahwa model pembelajaran kooperatif Number Heads Together (NHT) adalah model pembelajaran yang baik diterapkan dalam pembelajaran matematika sesusai dengan kurikulum 2013.

\section{Daftar Pustaka}
Aisyah, N. (2007). Bahan Ajar Cetak Pengembangan Pembelajaran Matematika SD. Jakarta: Depdiknas.

Arikunto, S. (2016). Dasar-Dasar Evaluasi Pendidikan. Bumi Aksara: Jakarta.

Asmani, J. (2016). Tips Efektif Cooperative Learning. Yogyakarta: Diva Press.

Asnany, Y. (2014). Efektifitas Model Pembelajaran Kooperatif Tipe TTW dalam Meningkatkan Hasil Belajar Matematika Siswa Kelas X SMA Negeri 7 Kendari. FKIP UHO : Kendari.

Djamarah, S. (2006). Strategi Belajar Mengajar. Jakarta: Rhineka Cipta.

Hendriana, H. (2014). Penilain Pembelajaran Matematika. Refika Aditama: Bandung.

Jihad, A. (2013). Evaluasi Pembelajaran. Yogyakarta: Multi

Marsi, N. (2014). Pengaruh Model Pembelajaran Kooperatif Tipe STAD dan Kemampuan Abstraksi Terhadap Prestasi Belajar Matematika Siswa. Juornal Program Pascasarjana Universitas Pendidikan Ganesha Program Studi Teknologi Pembelajaran Volume 4

Muhibbin, S. (2011). Psikologi Belajar. Jakarta: PT Raja Grafindo Persada.

Muhsetyo, G, dkk.(2008). Pembelajaran Matematika SD. Jakarta: Universitas Terbuka.

Nasution. (2006). Berbagai Pendekatan dalam Proses Belajar dan Mengajar. Bandung: Tarsito.

Nur, M. (2016). Pengaruh Penerapan Model Pembelajaran Kooperatif Tipe Numbered Head Together Terhadap Hasl Belajar Matematika Siswa Kelas VII SMP Negeri 1 Tongkuno. Skripsi U.H.O : Tidak Diterbitkan.

Poerwadarminta, (2003). Kamus Umum Bahasa Indonesia. Jakarta: Balai Pustaka. Pressindo.

Sanjaya, W. (2006). Strategi Pembelajaran. Jakarta: Kencana Prenada Media Group. 
Santoso, G. (2005). Metodologi Penelitian. Jakarta: Prestasi Pustaka.

Shoiman, A. (2016). 68 Model Pembelajaran Inovatif dalam Kurikulum 2013. ArRuzz Media, Yogyakarta.

Sudjana. (2005). Metoda Statistik. Bandung: Tarsito.

Sundayana, R.(2015). Statistika Penelitian Pendidikan. Bandung : Alfabeta.
Suparno, P. (2007). Filsafat Kontrukvisme dalam pendidikan. Yogyakarta: Kanisius.

Thobrani, M \& Arief Mustofa, (2013). Belajar dan Pembelajaran : Pengembangan Wacana dan Praktik Pembelajaran dalam Pembangunan Nasional. Yogyakarta : Ar-Ruzz Media. 